\author{
健聴者における足音の同定に関する研究 \\ 一聴覚障害者への実施に向けた基礎的検討一 \\ $\bigcirc$ 田原 敬 ${ }^{1} \cdot$ 小林優子 ${ }^{2} \cdot$ 原島恒夫 $^{3} \cdot$ 堅田明義 ${ }^{4}$ \\ $\left({ }^{1}\right.$ 筑波大学 障害学生支援室 ${ }^{2}$ 上越教育大学 臨床・健康教育学系 ${ }^{3}$ 筑波大学 人間系 $\cdot{ }^{4}$ 中部学院大学 人間福祉学部) \\ キーワード : 環境音, 聴覚表象, カテゴリー知覚
}

\title{
Identification of Footsteps Sounds in People with Normal Hearing
}

Kei Tabaru ${ }^{1}$, Yuko Kobayashi ${ }^{2}$, Tsuneo Harashima3 and Akiyoshi Katada ${ }^{4}$

( ${ }^{1}$ Office for Students with Disabilities, University of Tsukuba, ${ }^{2}$ Clinical Psychology, Health Care and Special Support Education, Joetsu University of Education, ${ }^{3}$ Faculty of Human Sciences, University of Tsukuba, ${ }^{4}$ Faculty of Human Well-Being, Chubu Gakuin University)

Key Words: Environmental Sound, Auditory Imagery, Categorical Perception

\section{目 的}

聴覚障害者は環境音認知に際して音響情報の時間パタンを 主な手がかりとして認知しているが、類似した時間パタンを 有する環境音の弁別が困難であるといった特徵がみられる

(Reed \& Delhorne, 2005)。この原因として、聴覚表象が十 分に形成されておらず（田原ら，2014）、カテゴリー知覚等が 困難になっている可能性が考えられる。しかしながら、環境 音の聴覚表象やカテゴリー知覚に関する報告は少なく、十分 な知見が得られていない現状にある。そこで、本研究では聴 覚障害者に先立ち健聴者を対象とし、各参加者の有する聴覚 表象を確認するための足音の再生課題と、カテゴリー知覚に ついて検討するための足音の同定課題を行い、聴覚障害者へ の実施に向けた基礎的資料を得ることを目的とした。

\section{方 法}

1 ）実験参加者 健聴の大学生、および大学院生 13 名。 2 ) 課題と刺激の作成 (1)再生課題: 机を 3 4 回叨いて歩く 音のリズムを再現する課題。(2)同定課題 : 刺激を聴取し、「歩 く音」か「走る音」かを判断してボタン押しで回答する課題。 同定課題では、女性の足音を一定の時間間隔で繰り返し、時 間間隔を変数とし、歩く音と走る音のリズムを再現した刺激 を用いた。具体的には、CD「新効果音大全集〈家庭・人間〉

(K30X5009)」の「ハイヒールで歩く」の一部（踵が地面に接 する際の音) を切り出し、ある一定の時間間隔で繰り返した。

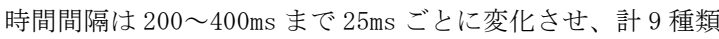
の刺激を作成した。各刺激の持続時間は $2000 \mathrm{~ms}$ に統一した。 3 ) 手続き 実験は(1)再生課題、(2)同定課題の順に実施した。 (1)再生課題: 利き手の甲で机を $3 \sim 4$ 回吒き、歩く音のリズム を再現した。(2)同定課題 : 本試行に先立ち練習試行を行い、 課題内容の理解と、呈示音圧 (MCL) が適切であるかどうかを 確認した。参加者は PC のキーボードの隣り合うボタン (任意) に利き手の人指し指と中指を置き、ヘッドホンから再生され た刺激をきいて、歩く音と判断した場合は人指し指のボタン を、走る音と判断した場合は中指のボタンを押して回答した。 9 種類の刺激を 15 回ずつランダムに呈示し、総試行数は 135 試行であった。

4) 分析 (1)再生課題における歩く音の間隔 : 再生課題にお いて各参加者が表現した音を録音し、音声編集用のソフトウ エア上でその時間間隔を測定し各参加者における平均間隔を 算出した。(2)同定課題における歩く音の同定間隔 : 刺激に対 して参加者が「歩く音」と回答した数を、各刺激の呈示回数 15 で除し、各刺激に対する歩く音の生起率を算出した。また、 13 回以上（生起率 $80 \%$ 以上， $p>$. 05）の回答がみられた時間間 隔については「歩く音の同定が可能である」とし、同定でき た時間間隔のうち最も短いものを「歩く音の同定間隔」とし た。分析に際し、生起率が $100 \%$ 至らなかった者、生起率が 不安定であった者を除き 11 名が分析の対象となった。
結 果
1 ) 再生課題における歩く音の間隔

再生課題では参加者間での個人差が大きく、時間間隔が最 も短いものが $251 \mathrm{~ms} 、$ 最も長いものが $827 \mathrm{~ms}$ であり、全体の 平均をみると $562(S D=170) \mathrm{ms}$ であった。

2 ）同定課題における歩く音の同定時間間隔（Fig. 1)

同定課題では同定時間間隔が $275 \mathrm{~ms}$ が 4 名、 $300 \mathrm{~ms}$ が 5 名、 $325 \mathrm{~ms}$ と $350 \mathrm{~ms}$ が 1 名ずつであった。

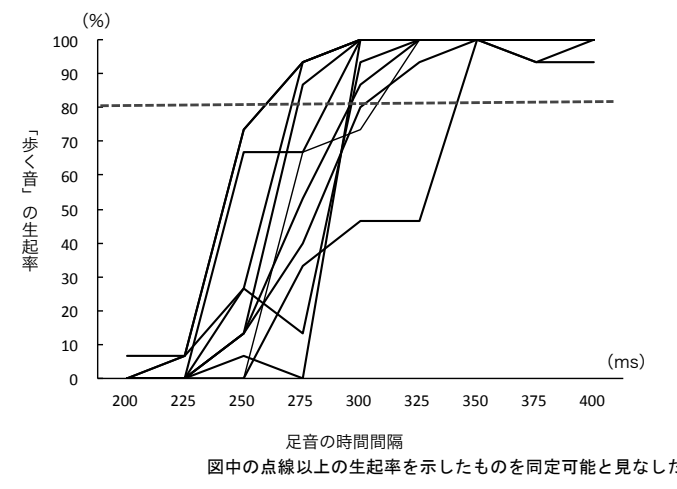

Fig. 1 各参加者における歩く音の生起率

\section{考 察}

同定課題においては分析対象者 11 名の内 9 名の同定時間間 隔が 275〜300ms の間にあることから、健聴者においては歩く 音のカテゴリー知覚に際して概ね同様の傾向を示すと示唆さ れた。そのため、今後聴覚障害者を対象とした実験を行う際 には、今回得られた同定間隔を基準として比較検討を行うこ とが可能であろう。一方で、再生課題における間隔と同定課 題での間隔には大きな差がみられた。この結果は、同一カテ ゴリーとして捉えることのできる聴覚表象の多様性を表して いるとも考えられる。今回の同定課題は「走る音」との弁別 的な要素も含まれているために、今後は極限法を用いて「歩 く音」として同定可能な間隔の上限及び下限を調べるなど、 より詳細を検討する必要がある。

\section{引用文献}

Reed, C. M. \& Delhorne, L.A. (2005) . Reception of environmental sounds through cochlear implants. Ear and Hearing, 26, 48-62.

田原敬・原島恒夫 ・ 小林優子 ・ 堅田明義（2014）. 聴覚障害者 における環境音の聴覚表象に関する研究. Audiology Japan, 57, 369-370. 